\title{
ALTERNATIVNI MODEL IZOLIRANJA SEKTORA U INPUT-OUTPUT SUSTAVU: METODOLOŠKI PRISTUP I PRIMJENA NA HRVATSKI IKT SEKTOR
}

Cilj ovog rada je razvoj alternativnog modela izoliranja sektora $u$ input-output sustavu za određivanje doprinosa sektora od interesa nacionalnom gospodarstvu te intenziteta međusektorske povezanosti sektora od interesa. Predloženi metodološki pristup primjenjiv je za onu grupu proizvodnih sektora koji uključuju više od jednog odjeljka klasifikacije u službeno objavljenim input-output tablicama. Model izoliranja sektora u input-output sustavu je primjenjiv za komparativnu analizu svih gospodarstava koja koriste istu klasifikaciju djelatnosti. Primjena modela izoliranja sektora u input-output sustavu empirijski je ilustrirana kvantificiranjem doprinosa i relativne mjere integracije sektora informacijsko-komunikacijskih tehnologija Republike Hrvatske. Na temelju rezultata provedene analize za 2010. godinu može se zaključiti da prerađivačka industrija informacijsko-komunikacijskih tehnologija zaostaje za uslužnim djelatnostima informacijsko-komunikacijskih tehnologija te da se relativna mjera integracije razlikuje za pojedine sektore informacijsko-komunikacijskih tehnologija.

Ključne riječi: alternativni model izoliranja sektora, input-output analiza, metoda hipotetskog izoliranja, miješani input-output model, sektor informacijsko-komunikacijskih tehnologija

\footnotetext{
* Dr. sc. D. Keček, viši predavač, Sveučilište Sjever, Sveučilišni centar Varaždin (E-mail: dkecek@unin.hr).

Rad je primljen u uredništvo 04.03.2019. godine, a prihvaćen je za objavu 03.04.2019. godine.
} 


\section{Uvodna razmatranja}

Doprinos određenog proizvodnog sektora nacionalnom gospodarstvu definira se kao zbroj izravnog, neizravnog i induciranog učinka. Izravni učinak promatranog proizvodnog sektora određen je izravnim isporukama dobara i usluga tog sektora krajnjim potrošačima. Neizravni učinak određenog sektora odnosi se na proizvodnju ostvarenu od svih sektora uključenih u cjelokupni proizvodni lanac određenog sektora, odnosno proizvodni lanac svih sektora koji proizvode intermedijarne proizvode te ih isporučuju promatranom sektoru. Osim izravnih i neizravnih učinaka, promatrani sektor generira i inducirane učinke koji su povezani s rastom potrošnje kućanstava, što potiče rast proizvodnje svih sektora uključenih u proizvodni lanac dobara i usluga namijenjenih krajnjoj potrošnji kućanstava. Izravni, neizravni i inducirani učinci kvantificiraju input-output (IO) analizom. Pokazatelji kojima se utvrđuju navedeni učinci nazivaju se multiplikatori. Razlikuju se dva tipa multiplikatora: multiplikator tipa I i multiplikator tipa II, ovisno o tipu IO modela, otvorenom ili zatvorenom IO modelu. Otvoreni IO model je onaj model u kojem se finalna potrošnja tretira kao egzogena varijabla. Za razliku od otvorenog modela u kojem su sve komponente finalne potrošnje egzogene, u zatvorenom modelu se za neke od komponenti pretpostavlja da su endogene, odnosno da su rezultat samog IO modela. Komponenta finalne potrošnje koja se uglavnom tretira kao endogena varijabla je osobna potrošnja koja u velikoj mjeri ovisi o ukupnoj proizvodnji, odnosno dohotku (Burrows i Botha, 2013; McLennan, 2006). Detaljnije o otvorenom i zatvorenom IO modelu vidjeti u Miller i Blair (2009), Mikulić (2018), ten Raa (2005). Ideja multiplikatora počiva na kvantificiranju razlike između inicijalnog učinka egzogene promjene finalne potražnje i ukupnih učinaka takve promjene (Miller i Blair, 2009). U otvorenom IO modelu ukupni učinci definirani su kao izravni i neizravni učinci. Multiplikatori tipa I uključuju izravne i neizravne učinke, a računaju se kao omjer ukupnog (izravnog i neizravnog) i inicijalnog učinka. U zatvorenom IO modelu ukupni učinci definirani su kao izravni, neizravni i inducirani. Multiplikatori tipa II prikazuje omjer između ukupnih učinaka koji uključuju izravne, neizravne i inducirane učinke, te inicijalne promjene finalne potražnje za outputom određenog sektora. ${ }^{1}$

Klasična IO metodologija može biti primijenjena u analizi utjecaja proizvodnih aktivnosti pojedinog sektora na ostale sektore gospodarstva, ali je njen doseg izračun multiplikatora tipa I i multiplikatora tipa II. Izračuni klasičnih multiplikatora ne daju sintetički pokazatelj doprinosa sektora gospodarstvu, već se inter-

${ }^{1}$ Detaljniji opis multiplikatora tipa I i multiplikatora tipa II vidjeti u Cassar (2015), Grady i Muller (1988), Miller i Blair (2009), Oosterhaven et al. (1986). 
pretiraju kao učinci promjene finalne potražnje na ukupnu gospodarsku aktivnost. Pojedini ekonomski sektori mogu proizvoditi dobra i usluge koji nisu namijenjeni osobnoj potrošnji ili drugim kategorijama finalne potražnje, poput proizvodnje sirove nafte, bazičnih metala ili različitih poslovnih usluga. Klasični IO pristup u kojem bi se doprinos takvih sektora ocjenjivao korištenjem isključivo finalne potražnje za njihovim outputom stoga bi podcijenio stvaran doprinos.

U recentnim empirijskim istraživanjima domaćih autora prevladava primjena klasičnog IO pristupa (Jurčić, 2000; Gorjan, Lovrinčević i Mikulić, 2003; Botrić, 2013). Najveći dio empirijskih istraživanja koristi kao metodološku osnovu samostalnu IO analizu (Buturac i Vizek, 2015; Lovrinčević, Buturac i Mikulić, 2015; Buturac, Lovrinčević i Mikulić, 2017; Ivandić i Šutalo, 2018; Buturac, Mikulić i Palić, 2019), dok se u novijim istraživanjima IO analiza kombinira s drugim metodama (Keček, Dušak i Žajdela Hrustek, 2015; Buturac, Lovrinčević i Mikulić, 2014).

U ranijoj literaturi razvijena su dva glavna pristupa za analizu utjecaja pojedinog sektora na ostale sektore gospodarstva koji se temelje na IO tablicama, a pomoću kojih se može odrediti doprinos sektora ukupnom gospodarstvu. To su miješani IO model (eng. mixed IO model) i metoda hipotetskog izoliranja (eng. hypothetical extraction method). Ukoliko je interes usmjeren na promatranje utjecaja egzogenih promjena outputa i finalne potražnje određenog sektora na output i finalnu potražnju preostalog broja sektora u gospodarstvu, primjenjuje se miješani IO model (Miller i Blair, 2009). Steinback (2004) modificirani klasični IO model u kojem se ne samo finalna potražnja, već i promjene u outputu tretiraju kao egzogene, naziva miješani model s egzogeno/endogenim varijablama. Ako je cilj analize isključivo usmjeren na analizu učinaka egzogenih promjena outputa pojedinih sektora na outpute preostalih sektora, za promjene u egzogeno zadanim finalnim potražnjama može se, prema Papadas i Dahl (1999), pretpostaviti da su jednake nuli. Miješani IO model primijenjen je u analizi učinaka sektora poljoprivrede (Papadas i Dahl, 1999), šumarstva (Eiser i Roberts, 2002) i ribarstva (Leung i Pooley, 2002) na nacionalna gospodarstva.

Osnovna ideja metode hipotetskog izoliranja je hipotetsko izoliranje jednog ili više sektora iz gospodarskog sustava i ispitivanje utjecaja izoliranih sektora na ostale sektore u gospodarstvu (Cella, 1984). Metoda hipotetskog izoliranja kvantificira izravan, neizravan i inducirani učinak izoliranih sektora na druge sektore ili na gospodarski sustav kao cjelinu (Dietzenbacher i Van Der Linden, 1997). Izvorna ideja metode hipotetskog izoliranja je kvantificirati koliko će se ukupna proizvodnja gospodarstva smanjiti ako se određeni sektor izolira iz gospodarskog sustava (Miller i Lahr, 2001; Dietzenbacher, van Burken i Kondo, 2019). Promatrani sektor se iz gospodarskog sustava izolira na način da se u matrici tehničkih koeficijena- 
ta $A=\left[a_{i j}\right]^{2}, i, j=1, \ldots, n$ obriše redak i stupac koji pripada tom sektoru. Umjesto brisanja retka i stupca iz matrice tehničkih koeficijenata, sektor od interesa se izolira zamjenom njegovog retka i stupca u matrici tehničkih koeficijenata nulama (Miller i Lahr, 2001; Miller i Blair, 2009). Miller i Lahr (2001) daju detaljan pregled svih mogućih načina izoliranja sektora u IO okviru zamjenom određenih elemenata matrice tehničkih koeficijenata nulama. Dietzenbacher i Lahr (2013) su generalizirali metodu hipotetskog izoliranja tako da se utjecaj određenih ekonomskih pojava mjeri uklanjanjem tih pojava iz IO tablice i ponovnim uravnoteženjem skupa IO računa. Pregledom relevantne literature utvrđeno je da je metoda hipotetskog izoliranja primjenjivana u analizi važnosti različitih sektora svjetskih gospodarstava. Song et al. (2005), Song et al. (2006b), Song i Liu (2007) i Ren et al. (2014) primjenom metode hipotetskog izoliranja analizirali su sektor poslovanja nekretninama. Utjecaj građevinskog sektora testirao je Song et al. (2006a). Guerra i Sancho (2010) su analizirali energetski sektor. Važnost uslužnih djelatnosti analizirali su Kay et al. (2007). Bazzazan (2009) je ispitao važnost sektora informacijsko-komunikacijskih tehnologija. Metoda hipotetskog izoliranja često je korišten pristup i u identifikaciji ključnih sektora gospodarstva (Andreosso-O'Callaghan i Yue, 2004; Temurshoev, 2009; Temurshoev, 2010; Yang et al, 2014; Guerra, 2014). U usporedbi s rezultatima dobivenima primjenom tradicionalnih IO metoda, autori zaključuju da metoda hipotetskog izoliranja daje bolje rezultate u identifikaciji ključnih sektora gospodarstva.

Cilj ovog rada je razvoj alternativnog modela izoliranja sektora od interesa pogodnog za izračunavanje ukupnog ekonomskog doprinosa sektora od interesa te intenziteta njihove međusektorske povezanosti. Za razliku od tradicionalnog pristupa u modelu izoliranja sektora, kao egzogeno zadana veličina ne koristi se finalna potražnja, već vrijednost outputa sektora od interesa.

Primjenom odgovarajućih analitičkih metoda, imajući u vidu raspoloživost usporedivih statističkih izvora, te u skladu s gore navedenim ciljem istraživanja, postavljena su sljedeća istraživačka pitanja:

1. Koliki je doprinos sektora od interesa nacionalnom gospodarstvu?

2. Kolika je relativna mjera integracije sektora od interesa?

Alternativni model izoliranja sektora prikazan u ovom radu može se koristiti za različite sektore od interesa, a posebice je doprinos u primjenjivosti takve metodološke osnovice za analizu doprinosa određenog ekonomskog fenomena koji agregira više od jednog sektora (energetika, transport i slično). Ograničenje prikazanog modela sastoji se u mogućnosti njegove primjene u komparativnoj analizi

\footnotetext{
2 Tehnički koeficijent $a_{i j}=\frac{x_{i j}}{x_{j}}$ prikazuje dio proizvoda sektora $i$ koji je potreban sektoru $j$ za proizvodnju jedne jedinice njegovog proizvoda.
} 
samo onih gospodarstava koja imaju raspoložive input-output tablice na istoj razini klasifikacije. Rad je strukturiran na sljedeći način: nakon uvodnog poglavlja dan je opis metodološkog okvira alternativnog modela izoliranja sektora u input-output sustavu. U trećem poglavlju prikazana je primjena alternativnog modela izoliranja sektora u input-output sustavu za kvantificiranje doprinosa i relativne mjere integracije sektora informacijsko-komunikacijskih tehnologija Republike Hrvatske. Posljednje poglavlje je zaključak s preporukama za daljnja istraživanja.

\section{Metodološki okvir alternativnog modela izoliranja sektora u input- output sustavu}

U ovom je radu prezentiran alternativni pristup izoliranja sektora u otvorenom IO sustavu. U svrhu izračuna induciranih učinaka primjenjuje se sličan pristup u zatvorenom IO sustavu. Ukoliko se output više sektora od interesa tretira kao egzogeni (umjesto finalne potrošnje), primjenom klasičnog pristupa temeljenog na upotrebi multiplikatora tipa I za izračun doprinosa sektora od interesa, dolazi do problema dvostrukog zbrajanja učinaka. Ukratko, problem dvostrukog zbrajanja učinaka nastaje zbog postojanja međusektorskih i unutarsektorskih isporuka između promatranih sektora od interesa, a uklanja se u dva koraka. U prvom koraku izračunaju se multiplikativni učinci po pojedinom promatranom sektoru od interesa korištenjem klasične primjene multiplikatora tipa I. U drugom se koraku uklanja lanac intermedijarne potrošnje vezan uz isporuke između promatranih sektora od interesa koje su dva puta zbrojene i to za vrijednost intermedijarne potrošnje koju pojedini promatrani sektor nabavlja od ostalih promatranih sektora.

\subsection{Model izoliranja sektora u input-output sustavu}

Neka je nacionalno gospodarstvo podijeljeno na $n$ proizvodnih sektora pri čemu je interes usmjeren na prvih $k$ sektora $^{3}$. Neka $X_{i}, i=1, \ldots, k$ predstavlja output ${ }^{4}$ prvih $k$ sektora od interesa za koje se izračunava doprinos te neka je $X_{i}=0, i=k+1, \ldots, n$ za preostalih $n-k$ sektora. Multiplikativni učinci $k$ sektora od interesa na svaki od

${ }^{3}$ Pozicija sektora od interesa ne utječe na izračun doprinosa tih sektora. Međutim, radi jednostavnosti i lakšeg razumijevanja određenih izvoda alternativnog modela izoliranja sektora, u nastavku je, od ukupno sektora nacionalnog gospodarstva, promatrano prvih sektora od interesa.

${ }^{4}$ Output sektora od interesa je tretiran kao egzogeno zadan, tj. određen je faktorima izvan samog modela. 
$n$ sektora gospodarstva u otvorenom IO sustavu jednaki su umnošku Leontief-ovog inverza $L=(I-A)^{-1}=\left[\alpha_{i j}\right], i, j=1, \ldots, n$ i vektora stupca outputa $X$.

U slučaju kad se umjesto finalne potražnje koristi zadani output sektora od interesa, zbroj izravnih i neizravnih učinaka promatranog sektora na sve sektore interesa veći je od egzogenog outputa promatranog sektora, $\mathrm{tj}$.

$$
\sum_{j=1}^{k} \alpha_{i j} \cdot X_{j}>X_{i}, i=1, \ldots, k
$$

Razlog veće vrijednosti outputa od zadane pripisuje se postojanju međusektorskih i unutarsektorskih isporuka između promatranih sektora, tj. u output pojedinog sektora već su obuhvaćeni prihodi od finalne potrošnje i međusektorskih izdataka od drugih sektora. Naime, output pojedinog promatranog sektora je u izračun učinaka uključen dva puta. Prvi put prilikom izračuna multiplikativnih učinaka promatranog sektora, a drugi put kao output isporučen drugom sektoru od interesa kao dio njegove intermedijarne potrošnje. Razliku izravnih i neizravnih učinaka svih sektora od interesa na output pojedinog promatranog sektora koji rezultiraju primjenom klasičnih multiplikatora te inicijalnih vrijednosti outputa pojedinog promatranog sektora, odnosno nastalo dvostruko zbrajanje

$$
\sum_{j=1}^{k} \alpha_{i j} \cdot X_{j}-X_{i}=d_{i}, i=1, \ldots, k
$$

potrebno je oduzeti od ukupnih učinaka, i to ne samo izravne već i odgovarajući neizravni učinak na ostale sektore. Obzirom da problem dvostrukog zbrajanja učinaka nastaje zbog međusektorskih i unutarsektorskih isporuka promatranih sektora od interesa, potrebno je odrediti vrijednost tih isporuka. Određivanje međusektorskih i unutarsektorskih isporuka, a što će rezultirati uklanjanjem nastalog dvostrukog zbrajanja, temeljeno je na rješavanju sustava $k$ linearnih jednadžbi sa $k$ nepoznanica. Rješenja sustava $k$ linearnih jednadžbi sa $k$ nepoznanica

$$
\sum_{j=1}^{k} \alpha_{i j} x_{j}=d_{i}, i=1, \ldots, k
$$

gdje su koeficijenti sustava $\alpha_{i j}, i, j=1, \ldots, k$ vrijednosti ukupnih isporuka svakog promatranog sektora od interesa po jedinici proizvodnje, slobodni koeficijenti sustava $d_{i}, i \quad 1, \ldots, k$ su poznate vrijednosti dvostrukog zbrajanja, a nepoznanice $x_{i}, i 1, \ldots, k$ inicijalne međusektorske i unutarsektorske isporuke, jesu vrijednosti

$$
x_{i}=\sum_{j=1}^{k} \widehat{\alpha_{i j}} d
$$


Nadalje, da bi se uklonio cijeli lanac intermedijarne potrošnje vezan uz isporuke između promatranih $k$ sektora od interesa koje su dva put uključene u izračun učinaka, najprije se računaju multiplikativni učinci svih sektora od interesa na svaki od $n$ sektora gospodarstva obzirom na vrijednosti međusektorskih i unutarsektorskih isporuka sektora od interesa množenjem Leontief-ov inverza vektorom stupcem međusektorskih i unutarsektorskih isporuka sektora od interesa $\boldsymbol{x}$. Konačno, oduzimanjem ukupno induciranih učinaka svih sektora od interesa i ukupne vrijednosti cijelog lanca intermedijarne potrošnje vezanog uz isporuke između svih sektora od interesa, a koja je vezana uz dvostruko zbrajanje učinaka, dobiva se doprinos $k$ sektora od interesa na svaki od $n$ sektora gospodarstva u otvorenom IO modelu.

Doprinos svakog pojedinog sektora od interesa na cijelo gospodarstvo, $\mathrm{u}$ oznaci $T_{j}^{0}$ jednak je

$$
T_{j}^{0}=\left(X_{j}-x_{j}\right) \cdot \sum_{i=1}^{n} a_{i j}, j=1, \ldots, k
$$

dok je doprinos $k$ sektora od interesa na cijelo gospodarstvo u otvorenom IO modelu jednak

$$
T^{0}=\sum_{i=1}^{n}\left(\sum_{j=1}^{k} \alpha_{i j} \cdot\left(X_{j}-x_{j}\right)\right)
$$

Kako je doprinos sektora od interesa u otvorenom IO modelu jednak zbroju izravnog i neizravnog učinka, pri čemu je izravni učinak sektora od interesa jednak egzogeno zadanom outputu sektora od interesa, tj. vrijednosti $X_{i}, i=1, \ldots, k$, to se neizravni učinak pojedinog sektora od interesa u otvorenom IO sustavu može izračunati prema

$$
N_{j}^{0}=T_{j}^{0}-X_{j}, j=1, \ldots, k
$$

a neizravni učinak $k$ sektora od interesa na cijelo gospodarstvo prema

$$
N^{0}=T^{0}-X
$$




\subsection{Međusektorske i unutarsektorske isporuke u otvorenom input-output sustavu}

Formula (4) prikazuje ukupnu vrijednost međusektorskih i unutarsektorskih isporuka $x_{i}, i=1, \ldots, k i$-tog sektora od interesa, tj. prikazuje vrijednost outputa koju $i$-ti sektor isporučuje sam sebi i svim ostalim sektorima od interesa. Osim ukupnih isporuka sektora od interesa, od posebne su važnosti i pojedinačne vrijednosti isporuka određenog sektora drugim sektorima od interesa kao i mjera integracije tih sektora. Zbroj pojedinačnih isporuka određenog sektora $i$ drugim sektorima od interesa jednak je ukupnoj vrijednosti međusektorskih i unutarsektorskih isporuka, tj. jednak je vrijednosti $x_{i}, i=1, \ldots, k$. Nakon eliminiranja izravnih isporuka $i$-tog sektora od interesa, vrijednost intermedijarne potrošnje $i$-tog sektora koja je utrošena u prvom sektoru od interesa je $\left(X_{1}-x_{1}\right) \alpha_{i 1}$, u drugom sektoru od interesa je $\left(X_{2}-x_{2}\right) \alpha_{i 2}$, u $i$-tom sektoru od interesa $\left(X_{1}-x_{1}\right)\left(\alpha_{i i}-1\right), \ldots$, dok je u $k$-tom sektoru od interesa vrijednost isporuka $\left(X_{k}-x_{k}\right) \alpha_{i k}, i=1, \ldots, k$. Navedene vrijednosti intermedijarne potrošnje predstavljaju isporuke između sektora od interesa. Relativna mjera integracije pojedinog sektora od interesa sa drugim sektorima od interesa, kao i sa svim ostalim sektorima nacionalnog gospodarstva, dobiva se tako da se svaka isporuka sektora $j=1, \ldots, k$ od interesa podijeli sa ukupnim neizravnim učincima tog istog sektora od interesa $\mathrm{i}$ to prema sljedećim formulama

$$
\rho_{i j}=\frac{\left(X_{j}-x_{j}\right) \alpha_{i j}}{\left(X_{j}-x_{j}\right)\left(\sum_{i=1}^{n} \alpha_{i j}-1\right)} l \neq j
$$

i

$$
\rho_{j j}=\frac{\left(X_{j}-x_{j}\right)\left(\alpha_{i j}-1\right)}{\left(X_{j}-x_{j}\right)\left(\sum_{i=1}^{n} \alpha_{i j}-1\right)}=\frac{a_{i j}-1}{\sum_{i=1}^{n} \alpha_{i j}-1}, l=1, \ldots, k
$$

što je pokazatelj integriranosti među sektorima, tj. relativna mjera integracije veća, to je razina međusektorske integracije viša. (Keček, 2018) 


\section{Primjena alternativnog modela izoliranja sektora $u$ input-output sustavu}

Informacijsko-komunikacijske tehnologije (IKT) smatraju se jednim od važniji pokretača kontinuiranog rasta i razvoja gotovo svakog nacionalnog gospodarstva. IKT omogućuju napredak društva u cjelini stvaranjem modela za poticanje rasta i razvoja nacionalnog gospodarstva, prijenosom i razmjenom informacija, znanja i tehnologija bez obzira na vremenske razlike ili geografsku udaljenost. IKT se smatra ključnim faktorom za konkurentnost, produktivnost i inovativnost kako na nacionalnoj, tako i na međunarodnoj gospodarskoj razini (Dedrick, Kraemer i Shih, 2013; Dewan i Kraemer, 2000; Popova, Popov i Dalin, 2005). Brojna istraživanja su potvrdila da IKT predstavlja tehnološku paradigmu koja pripada skupini tehnologija opće namjene. Guerrieri i Padoan (2007) definiraju tehnologije opće namjene kao nove ideje ili tehnike koje imaju značajan učinak na gotovo sve grane gospodarstva, a svako poboljšanje tehnologije za opće namjene izravno se odražava na sve grane gospodarstva u smislu povećanja njihove produktivnosti. Analizirajući svojstva tehnologije opće namjene, Qiu i Cantwell (2015) smatraju IKT naprednim tipom tehnologije opće namjene. Opće je prihvaćeno da se IKT, obzirom na druge današnje tehnologije, najbrže razvija i širi, a kao tehnologija opće namjene omogućava veću učinkovitost u postojećoj proizvodnji u cijelom gospodarstvu (Miller i Atkinson, 2014; Strauss i Samkharadze, 2011), brži rast produktivnost rada i veću ukupnu faktorsku produktivnost (Ceccobellia et al., 2012; O’Mahony i van Ark, 2003).

Velika brzina tehnoloških promjena u proizvodnji IKT dobara i usluga te sve učestalije korištenje IKT-a imaju značajan utjecaj ne samo na rast i razvoj IKT sektora, već i na produktivnost i učinkovitost svih ostalih sektora nacionalnog gospodarstva, a time i gospodarstva u cjelini. U razvijenim zemljama i u zemljama u razvoju IKT sektor je prepoznat kao pokretačka snaga gospodarstva te se IKT sektor smatra strateškim i visoko konkurentnim sektorom.

$\mathrm{S}$ ciljem prezentiranja vrijednosti alternativnog modela izoliranja sektora $\mathrm{u}$ IO sustavu, u nastavku ovog poglavlja dani su rezultati izračuna doprinosa IKT sektora hrvatskom gospodarstvu te mjere integracije između IKT sektora. Glavni izvor podataka za analizu utjecaja IKT sektora na hrvatsko gospodarstvo u ovom istraživanju je simetrična IO tablica hrvatskog gospodarstva za domaću proizvodnju za 2010. godinu objavljena od strane Državnog zavoda za statistiku Republike Hrvatske (2015). Prema europskim standardima objavljivanja IO tablica, IO tablica za Republiku Hrvatsku za 2010. godinu izrađena je na razini 65 proizvodna sektora koji su vezani uz odjeljke Nacionalne klasifikacije djelatnosti (NKD) 2007. Klasifikacija proizvoda koja je primjenjivana kod izrade IO tablica za 2010. 
godinu je Klasifikacija proizvoda po djelatnostima (KPD) 2008. Iako postoji 65 proizvodnih sektora u IO tablici, empirijski podaci za sektor šifre $U$ - Djelatnosti izvanteritorijalnih organizacija i tijela nisu raspoloživi pa je stoga sektor šifre $U$ - Djelatnosti izvanteritorijalnih organizacija i tijela isključen iz daljnje analize. Svi izračuni temeljeni su na osnovi međusektorskih vrijednosti preostala 64 proizvodna sektora. Definicija za identifikaciju IKT ekonomskih djelatnosti preuzeta iz Međunarodne standardne industrijske klasifikacije svih ekonomskih djelatnosti (ISIC) Rev. 4 (United Nations, 2008, p. 278). Definicija za identifikaciju IKT ekonomskih djelatnosti daje statističku osnovu za mjerenje onog dijela ekonomskih djelatnosti koje su generirane proizvodnjom IKT dobara i usluga. Uz navedeno, definicija omogućuje usporedivost IKT dobara i usluga na međunarodnoj razini. IKT djelatnosti dijele se u tri glavne grupe: prerađivačka industrija, trgovina i uslužne djelatnosti. U prilogu su obzirom na NKD 2007 na razini razreda, šifrom i opisom dane djelatnosti IKT grupa. Sektori IO tablice u koje se, između ostalih razreda, ubrajaju IKT razredi navedeni u prilogu, dani su šifrom i opisom kako slijedi:

- C26 Proizvodnja računala te elektroničkih i optičkih proizvoda Sektoru šifra C26 pripadaju razredi šifre 2610, 2620, 2630, 2640 i 2680.

- G46 Trgovina na veliko, osim trgovine motornim vozilima i motociklima Sektor šifra G46 između ostalih razreda obuhvaća razred šifre 4651 i 4652.

- J58 Izdavačke djelatnosti Razred šifre 5820 pripada sektoru šifra J58.

- J61 Telekomunikacije Razredi šifre 6110, 6120, 6130 i 6190 ubrajaju se u sektor šifre J61.

- J62_J63 Računalno programiranje, savjetovanje i djelatnosti povezane s njima

U sektor šifra J62_J63 uključeni su razredi 6201, 6202, 6209, 6311 i 6312.

- 595 Popravak računala i predmeta za osobnu uporabu i kućanstvo Sektor šifra $S 95$ uključuje razrede 9511 i 9512.

Sektori šifre C26, J61 i J62_J63 relativno su homogeni i gotovo u potpunosti obuhvaćaju aktivnosti koje pripadaju kategoriji IKT djelatnosti, dok sektori šifre G46, J58 i $S 95$ proizvode dobra i usluge koja nisu isključivo vezani uz IKT djelatnosti. Integracijom IO tablice i podataka iz Strukturnih poslovnih statistika (2018) odgovarajućim tehnikama izolirani su dijelovi IKT proizvodnje dobara i usluga u heterogenim sektorima. Za svaki od sektora šifre G46, J58 i S95 kreirana su po dva podsektora, jedan podsektor koji ima obilježja IKT djelatnosti i drugi koji nije svojstven IKT djelatnostima. Dezagregiranjem heterogenih sektora dobiveni su sljedeći sektori šifre i opisa svojstveni IKT djelatnostima: G46_IKT Trgovina 
na veliko specifična za IKT aktivnosti, J58_IKT Izdavačke djelatnosti svojstvene IKT djelatnostima i S95_IKT Popravak računala. Nakon transformacije sektora, dobivena je IO tablica sa 67 proizvodna sektora te je ista korištena u daljnjim empirijskim analizama.

Metodološki okvir alternativnog modela izoliranja sektora u IO sustavu prezentiran u prethodnom poglavlju primijenjen je za kvantificiranje doprinosa IKT sektora hrvatskom gospodarstvu u terminu outputa. Pored doprinosa IKT sektora, analizirana je i relativna mjera integracije između IKT sektora.

Tablica 1.

DOPRINOS POJEDINOG IKT SEKTORA U TERMINU OUTPUTA, U TISUĆAMA HRK

\begin{tabular}{|l|r|r|r|r|r|r|}
\hline & \multicolumn{1}{|c|}{ C26 } & G46_IKT & \multicolumn{1}{|c|}{ J58_IKT } & \multicolumn{1}{c|}{ J61 } & \multicolumn{1}{c|}{ J62_J63 } & S95_IKT \\
\hline Izravni učinak & 1814905 & 1333924 & 186502 & 9983748 & 8459287 & 485031 \\
\hline Neizravni učinak & 576857 & 754339 & 121153 & 2064611 & 3042849 & 170740 \\
\hline Doprinos & 2391762 & 2088263 & 307655 & 12048359 & 11502136 & 655771 \\
\hline
\end{tabular}

Izvor: Izračun autora.

Doprinosa IKT sektora u otvorenom IO sustavu definira se kao zbroj izravnih i neizravnih učinaka IKT sektora hrvatskom gospodarstvu. Na temelju formula (5) i (7) kvantificirani su učinci IKT sektora u terminu outputa za 2010. godinu. U Tablici 1 prikazane su vrijednosti doprinosa svih šest analiziranih IKT sektora. Razvidno je da je među IKT sektorima, sektor šifra J61 ostvario najveći doprinos na hrvatsko gospodarstvo u terminu outputa. U 2010. godini sektor šifra J61 generirao je više od 12 milijardi kuna ukupne hrvatske proizvodnje. S nešto manjim ukupnim učincima na output ističe se sektor šifra J62_J63. Najmanji doprinos zabilježen je za sektora šifra J58_ICT.

Prema formulama (9) i (10) izračunata je relativna mjera integracije pojedinog IKT sektora s ostalim IKT sektorima. Integracija IKT sektora grafički je prikazana na slici 1 . 


\section{Slika 1.}

\section{RELATIVNA MJERA INTEGRACIJE IKT SEKTORA U OTVORENOM IO SUSTAVU}

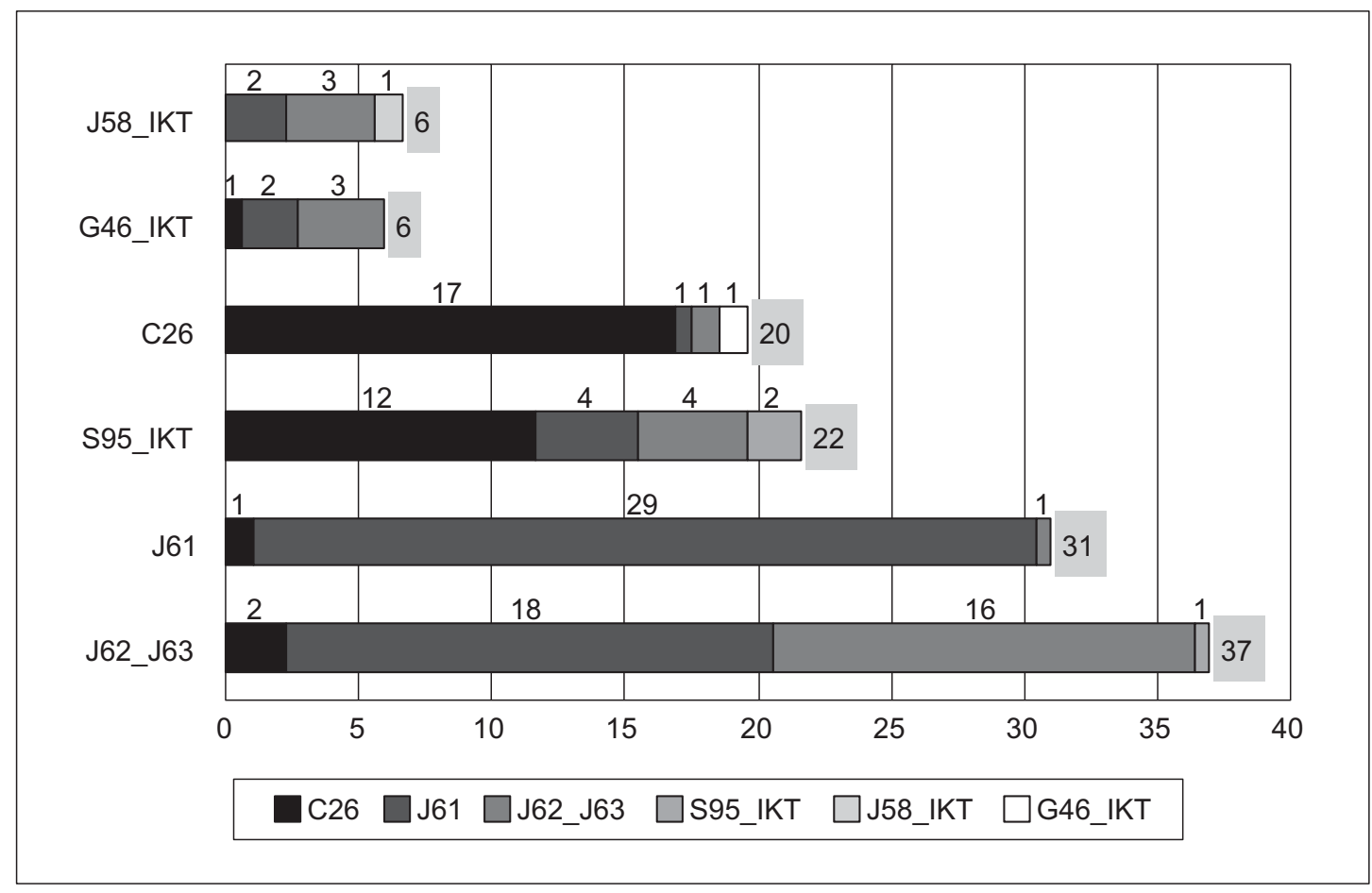

Izvor: Izračun autora.

Obzirom na relativnu mjeru integracije pojedinog IKT sektora s ostalim IKT sektorima, odnosno ostalim proizvodnim sektorima koji nemaju obilježja IKT djelatnosti, može se primijetiti da je sektor šifra J62_J63 imao najveći utjecaj na ostale IKT sektore, jer se čak $37 \%$ njegovih neizravnih učinaka odnosi na IKT sektore, i to ponajviše na sektore šifra J61 i J62_J63. Razvitak pojedinih kategorija usluga uključenih u sektor šifra J62_J63, poput programiranja, savjetovanja, obrade podataka i održavanja internet stranica međusobno se podupire i snažno je međusobno integriran. Razvitak takvih usluga podrazumijeva i raspoloživost kvalitetnih telekomunikacijskih usluga, prije svega širokopojasnih internetskih veza velike brzine, te je i u tom pogledu snažan tzv. backward učinak ovog sektora. S druge strane, i razvitak telekomunikacijskih usluga podrazumijeva određenu razinu informatičke podrške. Sektor šifra J61 je najviše povezan sam sa sobom. Visoki udio unutarsektorskih isporuka telekomunikacijskog sektora vezan je uz usluge između alternativnih telekomunikacijskih operatera međusobno povezanih na hrvatskom tržištu. Sektori šifra G46_IKT i J58_IKT slabo su integrirani s osta- 
lim IKT sektorima. Svega 6 \% neizravnih učinaka imaju na ostale IKT sektore, od čega najviše koriste dobra i usluge sektora šifre J61 i J62_J63. Kod sektora šifra $G 46 \_I K T$ i J58_IKT očita je njihova veća povezanom s ostalim djelatnostima koje nisu svojstvene IKT djelatnostima. Struktura intermedijarnih inputa koje troši sektor šifra G46_IKT više održava način poslovanja trgovačkih posrednika te je i njezin backward učinak na ostale IKT sektore relativno nizak, osim za određenu razinu informatičkih i telekomunikacijskih usluga. Sektor popravka računala, tj. sektor šifra $S 95 \_I K T$, zbog prirode posla zahtijeva značajan udio računalnih komponenti isporučenih iz sektora $C 26$, dok sektor proizvodnje računala, tj. sektor šifra $C 26$, osim unutarsektorskih isporuka računalnih komponenti ima vrlo mali utjecaj na razvoj ostalih IKT sektora. (Keček, 2018)

\section{Zaključak}

U cilju razvoja metodološkog pristupa za određivanje doprinosa sektora od interesa nacionalnom gospodarstvu te intenziteta međusektorske povezanosti sektora od interesa, u ovom je radu prikazan alternativni model izoliranja sektora $\mathrm{u}$ input-output sustavu. Predloženi model izoliranja sektora od interesa u IO sustavu omogućuje kvantificiranje doprinosa sektora od interesa, kao i relativne mjere integracije između promatranih sektora, što daje odgovor na postavljena istraživačka pitanja. Za razliku od klasične IO metodologije čiji je doseg izračun multiplikatora te miješanog IO modela i metoda hipotetskog izoliranja pomoću kojih se može odrediti doprinos sektora ukupnom gospodarstvu, alternativni model izoliranja sektora u input-output sustavu rješava problem dvostrukog zbrajanja učinaka koje nastaje primjenom klasičnog pristupa multiplikatora, odnosno nastaje kada se umjesto finalne potrošnje, output sektora od interesa tretira kao egzogeno zadan. Osim pokazatelja koji se odnosi na ukupne ekonomske učinke sektora od interesa, alternativni model izoliranja sektora u IO sustavu omogućuje prikaz međusobne povezanosti sektora od interesa. Naime, u određenom gospodarstvu proizvodni sektori mogu biti međusobno intenzivno povezani s drugim domaćim proizvođačima, što rezultira snažnim neizravnim učincima koji se šire na nacionalno gospodarstvo. S druge strane, određeni proizvodni sektor može biti važan za nacionalno gospodarstvo po pitanju njegovih ukupnih ekonomskih učinaka, ali inducira ograničene neizravne učinke na ostatak gospodarstva.

Alternativni model izoliranja sektora u IO sustavu testiran je na primjeru IKT sektora Republike Hrvatske. Na temelju rezultata provedene analize za 2010. godinu može se zaključiti da IKT prerađivačka industrija zaostaje za IKT uslužnim djelatnostima, zbog nižih vrijednosti doprinosa hrvatskom gospodarstvu. Relativna 
mjera integracije razlikuje se za pojedine IKT sektore. Sektor Računalno programiranje, savjetovanje i djelatnosti povezane s njima i sektor Telekomunikacije su međusobno najviše povezani. Sektori Trgovina na veliko specifična za IKT aktivnosti i Izdavačke djelatnosti svojstvene IKT djelatnostima slabo su integrirani s drugim IKT sektorima, tj. više su povezani s drugim hrvatskim proizvodnim sektorima.

Prezentirani metodološki pristup može se primijeniti za kvantificiranje doprinosa i mjera integracije na skupinu proizvodnih sektora koji uključuju više od jednog odjeljka klasifikacije, poput IKT sektora, sektora transporta i skladištenja ili energetskog sektora. Također, alternativni model izoliranja sektora u IO sustavu može se primijeniti za analizu svih gospodarstava koja koriste istu klasifikaciju djelatnosti.

U budućim istraživanjima očekuje se primjena alternativnog modela izoliranja sektora u IO sustavu za procjenu doprinosa IKT sektora hrvatskom gospodarstvu i relativne mjere integracije IKT sektora i za novije razdoblje na temelju IO tablice za 2015. godinu. Također, očekuje se primjena alternativnog modela izoliranja sektora u IO sustavu za procjenu doprinosa i relativnih mjera integracije IKT sektora za druga gospodarstva Europske unije. Komparativna analiza doprinosa i mjera integracija IKT sektora zemalja Europske unije omogućila bi sagledavanje utjecaja IKT sektora i šire spoznaje o važnosti IKT sektora ne samo na nacionalnoj, već i na međunarodnoj razini.

\section{Popis literature:}

Andreosso-O'Callaghan, B. i Yue, G. (2004). Intersectoral Linkages and Key Sectors in China, 1987-1997. Asian economic journal, 18, 165-183. DOI: https://doi.org/10.1111/j.1467-8381.2004.00188.x

Bazzazan, F. (2009). The economic importance of ICT in Iran - input-output approach. In: International Conference on Information and Financial Engineering. Singapore, IEEE, 1-7.

Burrows, L. R. i Botha, A. P. (2013). Explaining the changing input-output multipliers in South African: 1980-2010. In: Biennial Conference of the Economic Society of South Africa, Bloemfontein. (http://www.essa2013.org.za/fullpaper/essa2013_2636.pdf)

Botrić, V. (2013). Identificiranje ključnih sektora hrvatskog gospodarstva temeljem input-output tablice. Radni materijali EIZ-a, No. 2, 5-24. (https://hrcak.srce. hr/index.php?show=clanak\&id_clanak_jezik=160919) 
Buturac, G., Mikulić, D. i Palić, P. (2019). Sources of export growth and development of manufacturing industry: empirical evidence from Croatia. Ekonomska istraživanja, 32(1), 101-127. (https://doi.org/10.1080/133167 7X.2018.1550003)

Buturac, G., Lovrinčević, Ž. i Mikulić, D., (2014). Export Competitiveness of Croatian Textile Industry - CMS Analysis and Importance for Economy. Tekstil Ve Konfeksiyon, 24 (2), 158-168. (http://dergipark.gov.tr/tekstilvekonfeksiyon/issue/23644/251855)

Buturac, G., Lovrinčević, Ž. i Mikulić, D. (2017). International competitiveness and restructuring of the Croatian food industry, Acta Oeconomica, 67(3), 435-462. (https://akademiai.com/doi/10.1556/032.2017.67.3.7)

Buturac, G. i Vizek M. (2015). Izvoz prehrambene industrije i učinci na gospodarstvo: slučaj Hrvatske. Ekonomski pregled, 66(3), 203-230. (https://hrcak.srce. hr/index.php?show=clanak\&id_clanak_jezik=212247)

Cassar, I. P. (2015). Estimates of output, income, value added and employment multipliers for the Maltese economy. WP/03/2015. Malta, Central bank of Malta.

Ceccobellia, M., Gittoa, S. i Mancusoa, P. (2012). ICT capital and labour productivity growth: A non-parametric analysis of 14 OECD countries. Telecommunications Policy, 36(4), 282-292. (https://www.centralbankmalta. org/file.aspx?f=11220)

Cella, G. (1984). The Input-output Measurement of Interindustry Linkages. Oxford Bulletin of Economics and Statistics, 46(1), 73-84. DOI: https://doi. org/10.1111/j.1468-0084.1984.mp46001005.x

Dedrick, J., Kraemer, K. L. i Shih, E. (2013). Information Technology and Productivity in Developed and Developing Countries. Journal of Management Information Systems, 30(1), 97-122. DOI: https://doi.org/10.2753/MIS07421222300103.

Dewan, S. i Kraemer, K. L. (2000). Information Technology and Productivity: Evidence from Country-Level Data. Management Science, 46(4), 548-562. DOI: https://doi.org/10.1287/mnsc.46.4.548.12057

Dietzenbacher, E. i Van Der Linden, J.A. (1997). Sectoral and spatial linkages in the EC production structure. Journal of Regional Science, 37(2), 235-257. DOI: https://doi.org/10.1111/0022-4146.00053

Dietzenbacher, E., van Burken, B. i Kondo, Y. (2019). Hypothetical extractions from a global perspective. Economic Systems Research, 1-15. DOI: https:// doi.org/10.1080/09535314.2018.1564135

Dietzenbacher, E. i Lahr, M. L. (2013). Expanding Extractions. Economic Systems Research, 25(3), 341-360. DOI: https://doi.org/10.1080/09535314.2013.774266 
Državni zavod za statistiku Republike Hrvatske. (2015). Tablice ponude i uporabe i input-output tablice za 2010. Dostupno na: www.dzs.

Eiser, D. i Roberts, D. (2002). The Employment and Output Effects of Changing Patterns of Afforestation in Scotland. Journal of Agricultural Economics, 53(1), 65-81. DOI: https://doi.org/10.1111/j.1477-9552.2002.tb00006.x.

Gorjan, M., Lovrinčević, Ž. i Mikulić, D. (2003). Izračun matrice tehničkih koeficijenata republike hrvatske za potrebe input-output analize uz pomoć RAS metode. Ekonomski pregled, 54(5-6), 407-437. (https://hrcak.srce.hr/index. php?show=clanak\&id_clanak_jezik=40119)

Grady, P. i Muller, R. A. (1988). On the use and misuse of input-output based impact analysis in evaluation. The Canadian Journal of Program Evaluation, 3(2), 49-61. (https://ideas.repec.org/p/pra/mprapa/22063.html)

Guerra, A. I. i Sancho, F. (2010). Measuring Energy Linkages with the Hypothetical Extraction Method: An application to Spain. Energy Economics, 1-18. DOI: https://doi.org/10.1016/j.eneco.2009.10.017

Guerra, A. I. (2014). A proposal to combine classical and hypothetical extraction input-output methods to identify key sectors for the production and distribution of electricity. Energy Efficiency, 7, 1053-1066.

Guerrieri, P. i Padoan, P. C. (2007). Modelling ICT as a General Purpose Technology. Collegium, 35, 6-22.

Ivandić, N. i Šutalo, I. (2018). Doprinos turizma hrvatskom gospodarstvu: IO pristup. Ekonomski pregled, 69(1), 20-42. (https://hrcak.srce.hr/index. php?show=clanak\&id_clanak_jezik=288185)

Jurčić, Lj. (2000). Razvitak input-output analize u Hrvatskoj. Ekonomski pregled, 51(11-12), 1313-1333. (https://hrcak.srce.hr/index.php?show=clanak\&id_clanak_jezik=45251)

Kay, D. L., Pratt, J. E. i Warner, M. E. (2007). Role of Services in Regional Economy Growth. Growth and Change, 38(3), 419-442. DOI: https://doi. org/10.1111/j.1468-2257.2007.00377.x

Keček, D. (2018). Development and application of the modified model of ICT sectors extraction in the Croatian economy. Doctoral dissertation. Varaždin, University North.

Keček, D., Dušak, V. i Žajdela Hrustek, N. (2015). Sinergijski učinci input-output modela i Markovljevih lanaca za međusektorsku analizu. Privredna kretanja i ekonomska politika, 24(2), 37-60. (https://hrcak.srce.hr/index. php?show=clanak\&id_clanak_jezik=225272)

Leung, P. i Pooley, S. (2002). Regional Economic Impacts of Reductions in Fisheries Production: A Supply-Driven Approach. Marine Resource Economics, 16(4), 251-262. 
Lovrinčević, Ž., Buturac, G. i Mikulić, D. (2015). Export Performance of the Croatian Wood Industry and its Contribution to the Overall Croatian Economy. Forest products journal, 65 (3/4), 159-165. (https://forestprodjournals.org/doi/10.13073/FPJ-D-14-00063)

McLennan, W.(2006), Information paper: Australian national accounts: Introduction to input-output multipliers. No. 5246.0, Australian Bureau of Statistics. (http://www.abs.gov.au/AUSSTATS/abs@.nsf/DetailsPage/5246.0198990?OpenDocument)

Mikulić, D. (2018). Osnove input-output analize s primjenom na hrvatsko gospodarstvo. Zagreb: Ekonomski institut.

Miller, B. i Atkinson, R. D. (2014). Raising European Productivity Growth Through ICT. The information technology \& innovation foundation, 1-43. DOI: http://dx.doi.org/10.2139/ssrn.3079844

Miller, R. E. i Blair, P. D. (2009). Input-Output Analysis: Foundations and Extensions. New York: Cambridge University Press.

Miller, R. E. i Lahr, M. L. (2001). A taxonomy of extractions. In: Regional Science Perspectives in Economics: A Festschrift in Memory of Benjamin H. Stevens, Amsterdam, Elsevier Science, 407-441.

O'Mahony, M. i van Ark, B. (2003). EU Productivity and Competitiveness: An Industry Perspective. Can Europe Resume the Catching up process? Luxembourg: European Commission/Enterprise Publications. (https:// ec.europa.eu/digital-single-market/en/news/eu-productivity-and-competitiveness-industry-perspective-can-europe-resume-catching-process-pdf)

Oosterhaven, J., Gerrit, P. i Stelder, D. (1986). Theory and Practice of Updating Regional versus Interregional Interindustry Tables. Papers of the Regional Science Association, 59(1), 57-72. DOI: https://doi. org/10.1111/j.1435-5597.1986.tb00982.x

Papadas, C. T. i Dahl, D. C. (1999). Supply-Driven Input-Output Multipliers. Journal of Agricultural Economics, 50(2), 269-285. DOI: https://doi. $\operatorname{org} / 10.1111 /$ j.1477-9552.1999.tb00813.x.

Popova, I., Popov, O. i Dalin, R. (2005). ICT knowledge 4 ICT diffusion. Information and Communication Technologies and the Knowledge Economy, 2, 792-799.

Qiu, R. i Cantwell, J. (2015). Revisit the Classification of General Purpose Technologies (GPTs) in Corporate Innovation Research Using Patent and Patent Citation Data. International Information Management Association, 87-105.

Ren, H., Folmer, H. i Van der Vlist, A. J. (2014). What role does the real estate-construction sector play in China's regional economy? The Annals of Regional Science, 52, 839-857. DOI: https://doi.org/10.1007/s00168-014-0613-5 
Song, Y., Liu, C. i Langston, C. (2005). A linkage measures framework for the real estate sector. International Journal of Strategic Property Management, 9(3), 121-143. (https://journals.vgtu.lt/index.php/IJSPM/article/view/7271)

Song, Y., Liu, C. i Langston, C. (2006a). Linkage measures of the construction sector using the hypothetical extraction method. Construction Management and Economics, 24(6), 579-589. DOI: https://doi.org/10.1080/01446190500435358

Song Y., Liu C. i Langston, C. (2006b). Linkage measures of the real estate sector considering the effect of capital. International Journal of Strategic Property Management, 10, 131-143.

Song, Y. i Liu, C. (2007). An Input-Output Approach for Measuring Real Estate Sector Linkages. Journal of Property Research, 24(1), 71-91. DOI: https:// doi.org/10.1080/09599910701297697

Steinback, S. R. (2004). Using Ready-Made Regional Input-Output Models to Estimate Backward-Linkage Effects of Exogenous Output Shocks. The Review of Regional Studies, 34, 57-71. (https://journal.srsa.org/ojs/index.php/ RRS/article/view/78)

Strauss, H. i Samkharadze, B. (2011). ICT capital and productivity growth. EIB Papers, 16(2), 9-28. (https://www.econstor.eu/bitstream/10419/54664/1/682752967.pdf)

Strukturne poslovne statistike. (2018). Strukturne poslovne statistike. Dostupno na: https:/www.dzs.hr/Hrv/DBHomepages/Strukturne\%20poslovne\%20statistike/Strukturne\%20poslovne\%20statistike.htm.

Temurshoev, U. (2009). Hypothetical extraction and fields of influence approaches: integration and policy implications, Working Paper 09/06. Russia, EERC Research Network. (http://pdc.ceu.hu/archive/00005911/)

Temurshoev, U. (2010). Identifying optimal sector groupings with the hypothetical extraction method. Journal of regional science, 50(4), 872-890. DOI: https:// doi.org/10.1111/j.1467-9787.2010.00678.x

ten Raa, T. (2005). The Economics of Input-Output Analysis. Cambridge: Cambridge Univeristy Press.

United Nations. (2008). International standard industrial classification of all economic activities. Statistical papers, Series M No. 4/Rev.4, Revision 4, New York, Department of Economic and Social Affairs.

Yang, Z., Cai, J., Dunford, M. i Webster, D. (2014). Rethinking of the Relationship between Agriculture and the "Urban" Economy in Beijing: An Input-Output Approach. Technological and economic development of economy, 20(4), 624-647. DOI: https://doi.org/10.3846/20294913.2014.871661 
D. KEČEK: Alternativni model izoliranja sekora u input-output sustavu: metodološki pristup i primjena na hrvatski IKT sektor EKONOMSKI PREGLED, 70 (3) 431-450 (2019)

\section{PRILOG}

Šifra i opis IKT aktivnosti na razini razreda, prema NKD 2007:

IKT prerađivačke djelatnosti

2610 Proizvodnja elektroničkih komponenata i ploča

2620 Proizvodnja računala i periferne opreme

2630 Proizvodnja komunikacijske opreme

2640 Proizvodnja elektroničkih uređaja za široku potrošnju

2680 Proizvodnja magnetskih i optičkih medija

IKT trgovina

4651 Trgovina na veliko računalima, perifernom opremom i softverom

4652 Trgovina na veliko elektroničkim i telekomunikacijskim dijelovima i opremom

IKT uslužne djelatnosti

5820 Izdavanje softvera

6110 Djelatnosti žičane telekomunikacije

6120 Djelatnosti bežične telekomunikacije

6130 Djelatnosti satelitske telekomunikacije

6190 Ostale telekomunikacijske djelatnosti

6201 Računalno programiranje

6202 Savjetovanje u vezi s računalima

6209 Ostale uslužne djelatnosti u vezi s informacijskom tehnologijom i računalima

6311 Obrada podataka, usluge poslužitelja i djelatnosti povezane s njima

6312 Internetski portali

9511 Popravak računala i periferne opreme

9512 Popravak komunikacijske opreme 


\title{
ALTERNATIVE MODEL OF SECTORS EXTRACTION IN THE INPUT-OUTPUT SYSTEM: METHODOLOGICAL APPROACH AND APPLICATION TO THE CROATIAN ICT SECTOR
}

\author{
Summary
}

The aim of this paper is development of alternative model of sectors extraction in the inputoutput system to determine the contribution of sectors of interest to the national economy and the intensity of their inter-sectoral linkage. The proposed methodological approach is applicable to that group of productive sectors that include more than one classification section from officially published input-output tables. Model of sectors extraction in the input-output system is applicable for comparative analysis of all economies that use the same classification of activities. The application of the model of sectors extraction in the input-output system is empirically illustrated to quantify contribution and relative measures of integration of the information and communication technology sector in the Republic of Croatia. Based on the results of the conducted analysis for the year 2010 it can be concluded that manufacturing information and communication technology industry lags behind service information and communication technology activities and relative integration measure vary for some information and communication technology sectors.

Key words: alternative model of sectors extraction, input-output analysis, hypothetical extraction method, mixed input-output model, information and communication technology sector 